\title{
Need Assesment in Cooperative Development in West Java, Indonesia
}

\author{
Nataliningsih $^{1}$, Gijanto Purbo Suseno ${ }^{2}$ \\ ${ }^{1}$ Department of Agribusiness, Winayamukti University, Bandung, Indonesia \\ ${ }^{2}$ Department of Management, Cooperative Management Institut of Indonesia, Sumedang, Indonesia
}

Email address:

natalihuseina@gmail.com (Nataliningsih), giyantopurbosuseno@gmail.com (G. P. Suseno)

To cite this article:

Nataliningsih, Gijanto Purbo Suseno. Need Assesment in Cooperative Development in West Java, Indonesia. Advances in Sciences and Humanities. Vol. 5, No. 6, 2019, pp. 165-170. doi: 10.11648/j.ash.20190506.15

Received: November 22, 2019; Accepted: December 16, 2019; Published: December 26, 2019

\begin{abstract}
Based on data from the West Java Provincial Office of Cooperatives and SMEs (2015), out of a total of 25,741 cooperatives in West Java, $8886(35 \%)$ of them were inactive and 16,855 (65\%) were active. Whereas in Bandung City the total cooperatives were 2538 cooperatives, 1200 active $(47.3 \%)$ and $1338(52.7 \%)$ inactive cooperatives. In West Java Province there are 3 education and training institutions that foster cooperatives namely Balatkop, Lapenkop and Puskopdit, which continuously foster cooperatives and SMEs in developing their businesses. The phenomenon of the number of cooperatives that are not active shows that the training programs delivered by the cooperative training institutions have not been optimal. This study aims to measure the process of analyzing the needs of education and training conducted by the three education and training institutions in conducting cooperative training for cooperatives management and members. The research method used is a survey method to cooperatives that have participated in training activities as well as interviews with instructors and leaders of the relevant training and education institutions. The results of the study show that, a) identification of needs (to determine material, prospective participants, resource persons) training and b) identification stages of training material needs have not met the operational standards that should be. Identification of resource persons has fulfilled the requirements of the principal duties and functions of the trainer. There has been no consolidation among the three implementing education and training institutions in the implementation of needs assessment so that it is still possible to overlap training materials. It is necessary to prepare a road map to identify needs to be able to formulate training plans and formulations for the management and members of cooperatives in an integrated manner by the three cooperative training institutions.
\end{abstract}

Keywords: Need Assesment, Training, Cooperative

\section{Introduction}

The development of human resources substantially means the process of advancing, develop and enhance human resource capabilities, which are directed at physical progress (material) and non-material progress (knowledge, attitude and skills). According to the Chairman of the Cooperative Association of Lecturers and Researchers (ADOPKOP), Maryunani, in Davis, objectively recognized that the role of cooperatives in the Indonesian economy is relatively small compared to the private sector [1]. At least the main factor causing the lack of role of cooperatives and the decline in cooperative interest are sourced from the aspect of education, especially the quality of cooperative education that is not sufficient and equitable for human resources and cooperative cadres. So cooperative education needs to be given top priority for cooperative cadres. The non-formal education sector in the form of training can be delivered to cooperative cadres in order to develop the Indonesian economy through cooperatives.

Based on data from the West Java Provincial Office of Cooperatives and SMEs, out of a total of 25,741 cooperatives in West Java, 8886 (35\%) of them were inactive and 16,855 $(65 \%)$ were active. Whereas in Bandung City the total cooperatives were 2538 cooperatives, 1200 active (47.3\%) and 1338 (52.7\%) inactive cooperatives [2]. The high number of cooperatives that are not active requires its own thinking to find out the root of the problems that have an impact on 
these inactive cooperatives. Some of the factors that cause inactive cooperatives include low management competencies and lack of member participation, so that cooperative operations are stopped. Therefore, increasing the competence of administrators and member participation is needed so that there is a synergy between the cooperative management (including manager) who operate the cooperative, and the activeness of members as owners and customers.

According to Elena, the weak competitiveness of cooperatives in Indonesia is partly due to the lack of attention of cooperative management and the low managerial skills of cooperative management [3]. Sutisna et al research results, showed that the cooperative management education in West Java on average still low at $40 \%$ of university graduates, $52 \%$ of high school graduates, and $8 \%$ of junior high school graduates [4]. To follow up on this problem, it is necessary to conduct training for management and candidates for cooperative management. Education and training have been considered as essential parts of cooperative activities from the time the first society was found. One of the principles laid down by the ICA is that cooperatives should make provisions for the education and training of all stakeholders, which includes members, leaders, employees and public [5]. In West Java Province there are 3 training institutions that foster cooperatives, namely the Cooperative Training Center (Balatkop), the Cooperative Education Institute (Lapenkop) and the Credit Cooperative Center (Puskopdit), which continuously foster cooperatives and SMEs in developing their businesses. Balatkop is a government agency under the West Java Provincial Cooperatives and SMEs Office. Lapenkop is an education and training institution owned by the cooperative movement, while Puskopdit is a secondary cooperative from the Savings and Loans Cooperative (Credit Cooperative). Based on the fact that there are still non-active cooperatives up to $52.7 \%$ (1338 cooperatives) this indicates that there are indications that the material delivered by the three education and training institutions is not yet effective or not as needed. The suitability between the training material and the training participants' needs is very important so that the implementation of education and training becomes effective and efficient and the training objectives can be achieved as expected.

\section{Literature Review}

The importance of human capital in human development began in the 1960 s by the thought of Theodore Schultz regarding investment in human capital. Schultz, is known as the foundation of the Human Capital Investment Theory, which proves that the results of human capital investment through education and training are greater than those based on investment in physical capital [6]. Since the seventies Human Capital Theory has been applied in education outside of school. Education and training are the most important investments in human capital [7]. The training program can be held in education and training institutions, the work environment and the community. To achieve optimal results in the implementation of training, the first step that needs to be done is to conduct Training needs assessment.

To mobilize cooperatives, training and assistant / coaching techniques are needed regarding cooperative activities, the results of interviews with cooperative members indicate that cooperative members attend meetings designed by promoters and cooperative managers [8].

Training needs assessment is the determination of the difference between real conditions and desired conditions in the work of an organization in knowing, skills and attitudes. Need assessment is defined as the process of data collection and analysis, trough which the needs of individuals, groups, organizations and communities are identified [9]. The purpose of needs assessment according to Atmodiwirio is: 1) describes the true nature (exact) of a description of the implementation of work, 2) determines the causes of the description of the implementation of the work, 3) recommends a suitable solution, 4) describes the population of training participants [10].

The competency model in cooperative education identifies competency gaps between what education provides and what industries need, including 3 skill components, namely cognitive, technical, and behavioral skills, while competencies include behavioral competencies (patience, enthusiasm, willingness) and adaptability competencies [11].

Next, the needs assessment steps are: 1) the first step, identifying and describing the work implementation gap, 2) the second step, determining the causes of the gap, 3) the third step, identifying the work implementation gap based on lack of knowledge and skills, 4) step four, determine whether training is the possible solution, 5) step five, solution recommendation, 6) step six, describe the role or implementation of the task.

The formulation of the training program as a follow-up plan from the results of the needs assessment involves five components which according to Sumantri are: 1) training objectives, 2) training participants, 3) trainers, 4) training materials and 5) training methods. Whereas in terms of cooperative needs analysis carried out on: 1) cooperative management, 2) cooperative members, 3) cooperative finance, 4) cooperative documents, 5) cooperative performance, 6) results of the Cooperative Members' Meeting and compare with other more advanced cooperatives [12]. After obtaining a needs analysis, the level of importance of each of these needs is calculated, which is then obtained by the training materials, training participants and competent education and training instructors.

According to Konrad, need assessment is important in developing a cooperative to fit the needs of the cooperative itself [13]. Cooperatives emerged to develop institutional and organizational prerequisites for market access for example agriculture marketing cooperatives.

Viewed from the side of the training institution, needs assessment is emphasized to instructors (widyaiswara) who deliver the results of the needs assessment which can be viewed in terms of instructor education, instructor competence, instructor teaching methods, as well as the form 
and manner of material delivery. Therefore, every education and training institution can evaluate personal competencies, social competencies and professional competencies / academics from each instructor which is then followed up with an improvement in education and instructor competence. The suitability between the results of the needs analysis and the material and the ability of the instructor to convey is very directly related. The training process model according to Blanchard $\mathrm{N}$ and Thacker $\mathrm{J}$ shows that each training activity begins with a needs analysis, while follow-up after training is conducted at each stage of training management that still needs improvement. The training process model is as follows:

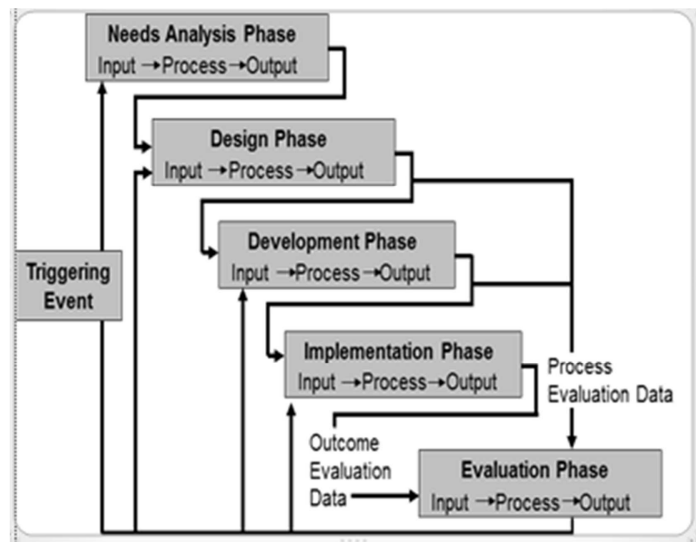

Figure 1. Training process model according to Blanchard N., and Thacker J. [14].

The process in needs assessment according to Blanchard and Thacker includes input, process and output [14] Needs assessment, the input is to conduct surveys and interviews with managers and members of cooperatives to obtain the problems faced today. Management issues related to service to members, management of cooperatives, preparation of documents, financial administration, development of service goods and so on. Whereas in terms of members, the needs assessment is emphasized on members' expectations, the current situation, as well as the objectives or vision and mission of the cooperative itself. Follow-up input is a process that is processing data from needs analysis according to Parker in Atmodiwirio, can be described as follows:

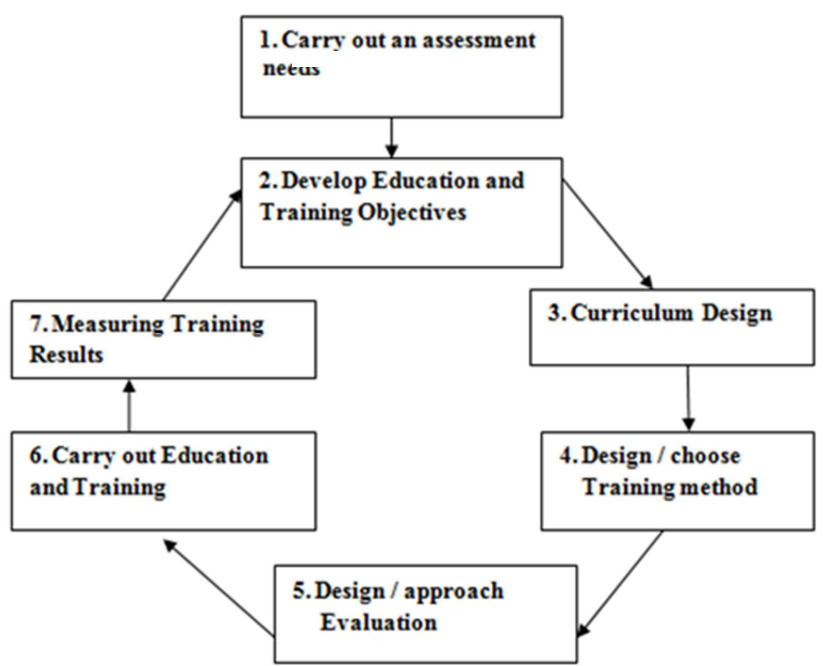

Figure 2. Model of Parker (in Atmodiwirio) [10].

Activity training model according to Marzuki, shows that training which focuses on improving employee competencies, the ability factor of trainers determines the effectiveness and success of training activities [15]. The results of the evaluation of training activities are monitored starting from the output in time series and outcome when implemented by the training results, so that a follow-up plan is obtained for the education and training institution itself. The activity trainning model is as follows:

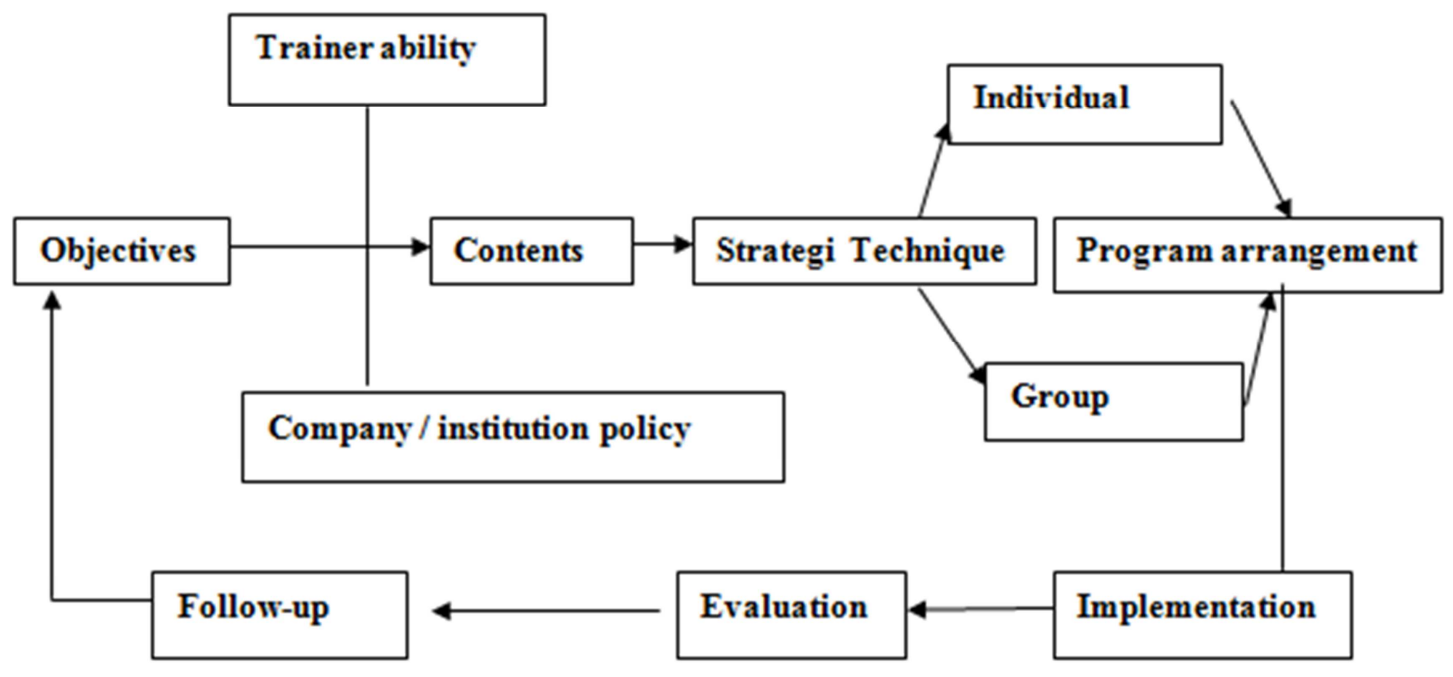

Figure 3. Model of activity training according to Marzuki [15].

The coooperatives characteristies result in greater capacity for intra and inter sectorial cooperation, including actions in 
the research and trainning system, cooperatives education system offers increasingly advanced studies to ensure an adequide flow of engineers, technologies and production workers [16].

\section{Research Methods}

This study uses a qualitative approach with descriptive methods, through surveys and interviews to cooperatives, cooperative administrators and cooperative members who have participated in training activities in 3 training institutions namely Balatkop, Lapenkop and Puskopdit West Java. With criteria always $=4$, often $=3$, rarely $=2$ and never $=1$.

\section{Results and Discussion}

\subsection{The Survey Results of Implementation of the Needs Assessment Carried out by Three Institutions}

The results of the survey and interviews with management, members, and education and training institutions related to the needs analysis before the implementation of training in outline are presented in the table as follows:

Table 1. The results of the assessment of the implementation of the training needs assessment in three institutions.

\begin{tabular}{|c|c|c|c|c|}
\hline No & $\begin{array}{l}\text { Training Institutions Stages of Need } \\
\text { Analysis }\end{array}$ & BALATKOP & LAPENKOP & PUSKOPDIT \\
\hline 1 & $\begin{array}{l}\text { Identification of the training material } \\
\text { needs to cooperative management }\end{array}$ & $\begin{array}{l}\text { Rarely done because it is not } \\
\text { included in the Principal Task and } \\
\text { Function (Tupoksi) of the instructor } \\
\text { (widyaiswara) }\end{array}$ & $\begin{array}{l}\text { Often done through field } \\
\text { guides }\end{array}$ & $\begin{array}{l}\text { Always done through } \\
\text { meetings, indirectly through } \\
\text { the field facilitator, or by the } \\
\text { management's request }\end{array}$ \\
\hline 2 & $\begin{array}{l}\text { Identification of training material } \\
\text { needs for cooperative members }\end{array}$ & $\begin{array}{l}\text { Rarely done because it is not } \\
\text { included in the training institution's } \\
\text { Tupoksi }\end{array}$ & $\begin{array}{l}\text { Rarely done, because those } \\
\text { who meet members of the } \\
\text { cooperative are Field } \\
\text { Guides }\end{array}$ & $\begin{array}{l}\text { Always done through } \\
\text { meetings, indirectly through } \\
\text { field facilitators, or member } \\
\text { requests }\end{array}$ \\
\hline 3 & $\begin{array}{l}\text { Identification of training material } \\
\text { needs to the training instructor }\end{array}$ & $\begin{array}{l}\text { Always done usually at the } \\
\text { beginning of the year, to prepare } \\
\text { instructors for } 1 \text { year of training }\end{array}$ & $\begin{array}{l}\text { Always done, if the internal } \\
\text { instructor is unable, an } \\
\text { external instructor can be } \\
\text { invited }\end{array}$ & $\begin{array}{l}\text { Always done through meetings } \\
\text { of all instructors }\end{array}$ \\
\hline 4 & $\begin{array}{l}\text { Identify prospective trainees (learning } \\
\text { citizens) }\end{array}$ & $\begin{array}{l}\text { Never done, by spreading the letter } \\
\text { to the district / city, whoever sent it }\end{array}$ & Always done & $\begin{array}{l}\text { Never done, based on } \\
\text { awareness, because only those } \\
\text { who pay join the training }\end{array}$ \\
\hline 5 & $\begin{array}{l}\text { Identification of infrastructure needs } \\
\text { for learning citizens }\end{array}$ & $\begin{array}{l}\text { Never done, using the training } \\
\text { building itself }\end{array}$ & $\begin{array}{l}\text { Rarely done, training } \\
\text { activities are carried out at } \\
\text { the hotel }\end{array}$ & $\begin{array}{l}\text { Often done, training activities } \\
\text { are carried out in meeting halls } \\
\text { or hotels according to budget }\end{array}$ \\
\hline 6 & Goal setting & $\begin{array}{l}\text { Always done during training } \\
\text { orientation }\end{array}$ & $\begin{array}{l}\text { Always done to support the } \\
\text { vision and mission }\end{array}$ & $\begin{array}{l}\text { Always done, so that } \\
\text { participants understand }\end{array}$ \\
\hline 7 & $\begin{array}{l}\text { Preparation of education and training } \\
\text { curriculum }\end{array}$ & $\begin{array}{l}\text { Always done, referring to the } \\
\text { National Cooperative and SME } \\
\text { curriculum }\end{array}$ & $\begin{array}{l}\text { Always done, curriculum } \\
\text { preparation } \\
\text { standard }\end{array}$ & $\begin{array}{l}\text { Often done, especially for } \\
\text { trainings whose material must } \\
\text { always be updated with high } \\
\text { intensity (eg tax training) and } \\
\text { trainings that have never been } \\
\text { held before }\end{array}$ \\
\hline 8 & $\begin{array}{l}\text { Preparation of guidelines for } \\
\text { instructors }\end{array}$ & $\begin{array}{l}\text { Never been done, because the } \\
\text { instructor is considered to be } \\
\text { capable and part of their job } \\
\text { (tupoksi) }\end{array}$ & $\begin{array}{l}\text { Always done, standard } \\
\text { guidelines for instructors } \\
\text { and guides are prepared }\end{array}$ & $\begin{array}{l}\text { Rarely done, because the } \\
\text { instructors who provide } \\
\text { training are fixed, only for new } \\
\text { instructors }\end{array}$ \\
\hline 9 & Instructor selection & $\begin{array}{l}\text { Often done, by cooperating by } \\
\text { bringing resource persons from } \\
\text { universities / chambers of } \\
\text { commerce and industry }\end{array}$ & $\begin{array}{l}\text { Always done by Lapenkop } \\
\text { region / area Lapenkop }\end{array}$ & $\begin{array}{l}\text { Often done. adapted to the } \\
\text { training material }\end{array}$ \\
\hline 10 & Selection of training participants & $\begin{array}{l}\text { Never done, in collaboration with } \\
\text { the district / city office }\end{array}$ & $\begin{array}{l}\text { Often done by the regional } \\
\text { Indonesian cooperative } \\
\text { council }\end{array}$ & $\begin{array}{l}\text { Rarely done, training } \\
\text { participants are selected by } \\
\text { primary credit cooperatives } \\
\text { who send participants }\end{array}$ \\
\hline 11 & $\begin{array}{l}\text { Identification of infrastructure needs } \\
\text { for the implementation of education } \\
\text { and training }\end{array}$ & $\begin{array}{l}\text { Rarely done, according to room } \\
\text { standards, even if done by } \\
\text { spreading an evaluation } \\
\text { questionnaire at the end of the } \\
\text { training }\end{array}$ & $\begin{array}{l}\text { Never done, standard office } \\
\text { stationery }\end{array}$ & $\begin{array}{l}\text { Often done regularly, } \\
\text { according to the needs and } \\
\text { budgets }\end{array}$ \\
\hline 12 & $\begin{array}{l}\text { Delivery or dissemination of training } \\
\text { letters }\end{array}$ & Always done, via post / fax / email & $\begin{array}{l}\text { Rarely done, done by } \\
\text { telephone and invitation by } \\
\text { a guide }\end{array}$ & $\begin{array}{l}\text { Often done routinely in } \\
\text { accordance with work } \\
\text { programs }\end{array}$ \\
\hline 13 & Cooperation with similar institutions & $\begin{array}{l}\text { Never done, because this institution } \\
\text { belongs to the government }\end{array}$ & $\begin{array}{l}\text { Often done, through visits } \\
\text { to similar institutions, and } \\
\text { advanced cooperatives }\end{array}$ & $\begin{array}{l}\text { Never done, do the institution } \\
\text { development first }\end{array}$ \\
\hline & Total value & 30 & 40 & 37 \\
\hline
\end{tabular}


Balatkop as a government education and training institution works in accordance with the main tasks and functions that have been determined in supporting the institution's performance and instructor (widyaiswara) performance, so the needs assessment is not done in detail.

In one year, the material presented was only 1 training material, but was intended for all cooperative administrators in West Java. This activity is mainly to support the vision and mission of the Ministry of Cooperatives and MSMEs. Because the type of training material presented is only one example of the title "Managerial and Entrepreneurial Training in the Field of Accounting for Cooperative Administration and Finance Managers", some cooperatives feel that they are not in accordance with their needs, which results in sending participants who are not in accordance with their duties. Judging from the instructor's side, Balatkop has instructors (widyaiswara) with clear tasks and functions (tupoksi) so that they support the training material presented.

Lapenkop is a cooperative movement education and training institution whose funds come from the area Lapenkop (Lapenkopda) and regional Lapenkop (Lapenkop wilayah) subsidies and from the training participants, especially from the government through the Indonesian Cooperative Council (commonly called DEKOPIN). The training materials that will be held have been through analysis of participants' needs, therefore selection of participants and instructors is carried out so that the training activities are carried out as effectively and efficiently as possible. The formation of field guides reached 2,142 people spread in 30 provinces or 244 districts / cities as part of the needs assessment in the field where the results were used as an evaluation of training needs. Lapenkop's main objective is to increase community participation in cooperation, while the support is the development of cooperative management so that some training materials have been prepared and offered, among others: Training for Cooperative Members (I-IV), Basic Guidance Training (I-II), Training for Trainers, Training for Cooperative Administrators, Training for Cooperative Supervisors, Modern Retail Training, Cooperative Accounting Training, Small Business Management Training, Entrepreneurship Training.

Puskopdit is a secondary cooperative of Credit Cooperatives or Savings and Loans Cooperatives (KSP), a private institution engaged in the development of cooperatives. The development of Puskopdit is entirely dependent on primary cooperatives, so that in managing the needs assessment is carried out by involving members and administrators of primary cooperatives. Financing for the implementation of education and training is fully borne by participants, both members and management of the cooperative. Therefore, the material offered is tailored to the needs of participants. Currently there are 5 main training topics, namely 1) Accounting Specialization Training, 2) Basic Credit Cooperative Management Training, 3) CS Siskopdit Operator Training, 4) Small Business Management Training and 5) Tax Training. At the beginning of the year all topics and schedules are offered to members of the primary cooperative, in return in the form of topics to be followed.

Based on Table 1 above, it can be seen that all education and training institutions have not fully carried out a needs assessment because of the type of institution, the purpose of the institution, funding sources and institutional management. Material identification, prospective participants and training instructors are very important so that training is more efficient. Cooperation has never been carried out to design cooperative development strategies so that there is overlapping material, such as accounting training, all institutions implement it, so it is less effective and efficient.

From the observations showed that from those three institutions no one had conducted detailed needs identification activities, such as in the library theory of Blanchard N and Thacker J, Admodiwirio, Marzuki S,. The results of field observations for Balatkop tend to adjust to government policy, Lapenkop tends to provide all the training materials and the board / members choose which material is needed. Puskodit, needs identification activities are carried out by holding joint meetings and then determining the types of training to be conducted, so that the management / members want to contribute to the training activities.

\subsection{Identification and Stages of Needs Assessment That Should Be Done}

Based on the table above shows that each institution has advantages and disadvantages in implementing the training. All institutions have not fulfilled and have not carried out every step in the identification of needs. Balatkop as a government education and training institution does not carry out the preparation of instructor guides, selection of participants, identification of pre-facility facilities needed by participants and implementation of training, this occurs because the training instructors come from civil servants ( $P N S$ ) so that it has become the main duties and functions (tupoksi) of employees, the means of pre-facilities in accordance with those in the training building and training participants are left entirely at the appointment of cooperatives. The advantage of Balatkop is that it can organize training for 900 participants in each year.

Lapenkop has advantages, namely the type of training material offered is very complete, but because participants pay for themselves, the ability of the cooperative or individual determines the implementation of this training program is low. The drawback is not to identify pre-facility facilities due to the implementation of training in the hotel. The lack of Lapenkop is that its sustainability is determined by the participation of cooperatives and the community and the cooperative movement in supporting the operation of each education and training activity.

Puskopdit has advantages, namely identifying the material needs to determine the training material that will be offered, so that it prioritizes the suitability of the material with the needs of the management and members. Training participants 
are management or members who need the training material so that based on the awareness of the management or members of the cooperative. The development of primary cooperative development is one way to conduct needs assessment. The disadvantage is that the sustainability of this institution is highly dependent on the participation of primary cooperatives through participation in training activities.

The stages of training needs assessment are carried out so that the training material that will be delivered is in accordance with the needs of the cooperative community. Broadly speaking the stages of needs analysis (assessment) are as follows:

a. Dissemination of activities for needs analysis through Participation Cooperative Appraisal (PCA).

b. Exploring the need for education and training through submission of problems, the way each board member / cooperative member is given $10 \times 10 \mathrm{~cm}$ paper, then asked to write 3 main problems that are felt as the board / cooperative members in managing their cooperative.

c. Identify common problems in managing cooperatives through tabulation of data from probing problems and then selecting the 5 highest problems.

d. The selection process of the main problems faced by the cooperative boards/ members through the Q-short method, the way each board / member is given 3 papers / marbles to choose 3 main problems that need to be addressed immediately.

e. Identify 3 main problems that will be followed up with training, how to vote for the results of the $\mathrm{Q}$ short method.

f. Sequence analysis of the importance of the 3 main problems resulting from the identification of problems, the way the board / members provide an assessment with criteria, is very important, important, quite important, less important and not important.

g. Conclusion of the results of the identification of problems that are followed up with the preparation of planning activities for training.

\section{Conclusions and Recommendations}

\subsection{Conclusion}

Based on the results of the study it can be concluded:

a. Identification of needs is done to determine material, prospective participants, resource persons of training.

b. The stages of identifying training material needs have not met the operational standards they should be. Identification of resource persons in Balatkop has fulfilled the requirements of basic tasks and instructor (widyaiswara) functions.

c. There has not been any consolidation among the three implementing education and training institutions in the implementation of needs assessment so that it is still possible to overlap the training material.

\subsection{Suggestion}

It is necessary to prepare a road map to identify needs to be able to formulate training plans and formulations for the management and members of cooperatives in an integrated manner by the three cooperative training institutions.

\section{References}

[1] Davis, P. (2010). Mengembangkan Keunggulan Koperasi (Terjemahan). Jakarta: LSP2I.

[2] Dinas KUKM Jabar (2015). Data Koperasi Tidak Aktif Jabar (in bahasa).

[3] Elena (2009). Persoalan dan Pemecahan Masalah yang dihadapi Koperasi Indonesia Saat ini (Online). Tersedia: http://alena 19 wordpress.com/2009/11/17/i-persoalan-dan-pemecahan-yangdihadapi-koperasi-indonesia-saat-ini/ (in bahasa).

[4] Sutisna dkk (2017). Koperasi Sebagai Pusat Inovasi dan Daya Saing Usaha Anggota yang Berkelanjutan. Bandung: Unpad (in bahasa).

[5] Bekele A. D. and Pillai G. B., (2011). "Training needs of members incoperative dairy marketing in Ethiopia". African Journal of Agriculture, 6 (2), 488-507.

[6] Baron, A. \& Amstrong, M. (2007). Human Capital Manajement. UK \&USA: Kogan Page Ltd.

[7] Becker, G. S. (1993). Human Capital. USA: The National Berau of Economic Research.

[8] T. Abebe (2010). Assesment of The Difficulties Foced by Women Cooperatives: The Case of Malga District, Sidama Zone, SNNPR, Ethiopia.

[9] Gilan, Nader Rajabi et al (2012). "Training Needs Assessment of Cooperatives in Aplicable Technical and Vocational Educations in Kermanshah (Iran)". Journal of Applied Sciences, 12 (21), 2225-2234.

[10] Atmodiwirio, S. (2002). Manajemen Pelatihan. Jakarta: PT Ardadizya Jaya (in bahasa).

[11] Worawit J., Ridha D., Nopasit C., 2016. A Cooperative Education Learning Framework to Develop Undergraduate Studen't Work Competencies. ISBN 9781851432516, Chiang Mai University, Chiang Mai Thailand.

[12] Sumantri, S. (2001). Pelatihan dan Pengembangan) Sumber Daya Manusia. Bandung: Unpad (in Bahasa).

[13] Konrad H, 2013. Natural Resource Management: the Role of Cooperative Institutions and Govermance, JEOD, Volume 2, Isuue 1, 101-121, 2 September 2013.

[14] Blanchard, P. N., and Thacker, J. W. (2004). Effective Training: System, Strategies and Practices. New Jersey: Pearson, Prentice Hall.

[15] Marzuki, M. S. (1992). Strategi dan Model Pelatihan: Suatu Pengetahuan Dasar Bagi Instruktur dan Pengelola Lembaga Pelatihan, Kursus dan Penataran. Malang: Jurusan PLS, FIP, IKIP. (in bahasa).

[16] Juan R., Gallego B., Rafael C-A., 2016. Innovation Cooperative Systems and Structural Change: an Evolutionary Analysis of Aneecoop and Mondragon Cases, JBR 09016, Elsevier, University of Valencia, Spain. 